\title{
Experiences from site-specific landslide early warning systems
}

\author{
C. Michoud ${ }^{1}$, S. Bazin ${ }^{2}$, L. H. Blikra ${ }^{3}$, M.-H. Derron ${ }^{1}$, and M. Jaboyedoff ${ }^{1}$ \\ ${ }^{1}$ University of Lausanne, Lausanne, Switzerland \\ ${ }^{2}$ Norwegian Geotechnical Institute, Oslo, Norway \\ 3 Åknes/Tafjord Beredskap, Stranda, Norway \\ Correspondence to: C. Michoud (clement.michoud@unil.ch)
}

Received: 30 November 2012 - Published in Nat. Hazards Earth Syst. Sci. Discuss.: -

Revised: 20 September 2013 - Accepted: 25 September 2013 - Published: 22 October 2013

\begin{abstract}
Landslide early warning systems (EWSs) have to be implemented in areas with large risk for populations or infrastructures when classical structural remediation measures cannot be set up. This paper aims to gather experiences of existing landslide EWSs, with a special focus on practical requirements (e.g., alarm threshold values have to take into account the smallest detectable signal levels of deployed sensors before being established) and specific issues when dealing with system implementations. Within the framework of the SafeLand European project, a questionnaire was sent to about one-hundred institutions in charge of landslide management. Finally, we interpreted answers from experts belonging to 14 operational units related to 23 monitored landslides. Although no standard requirements exist for designing and operating EWSs, this review highlights some key elements, such as the importance of pre-investigation work, the redundancy and robustness of monitoring systems, the establishment of different scenarios adapted to gradual increasing of alert levels, and the necessity of confidence and trust between local populations and scientists. Moreover, it also confirms the need to improve our capabilities for failure forecasting, monitoring techniques and integration of water processes into landslide conceptual models.
\end{abstract}

\section{Introduction}

Landslides are frequent phenomena in many natural environments, and remediation measures ought to be implemented in areas with high risk due to the presence of populations or infrastructures. Structural remediation measures have been extensively used for reducing and even eliminating the hazard (Piteau and Peckover, 1978; Holtz and Schuster, 1996;
Wyllie and Mah, 2004; Cornforth, 2005; Vaciago et al., 2011). However, classical countermeasures, such as modifications of mass distributions or water regimes, are often too expensive or difficult, if not impossible, when dealing with complex instabilities of large volumes (Crosta and Agliardi, 2003; Blikra, 2012).

In such situations, other types of mitigations have to be performed in order to decrease the risk, mainly imposed on human lives. A proper measure is to reduce the number of exposed people by implementing reliable landslide early warning systems (EWSs) that are capable of alerting and evacuating populations based on the monitoring of stability conditions of the landslide (e.g., parameter values exceeding established thresholds). Indeed, EWSs are defined by the United Nations as "the set of capacities needed to generate and disseminate timely and meaningful warning information to enable individuals, communities and organizations threatened by a hazard to prepare and to act appropriately and in sufficient time to reduce the possibility of harm or loss" (UNISDR, 2009). Efficient landslide EWSs require four major elements that have to be well integrated: (1) risk assessment, (2) phenomenon monitoring and forecasting, (3) warning communication and alert dissemination, and (4) local response aptitudes (UN-ISDR, 2009).

These elements have been described in detail in many papers, and useful concepts and recommendations can be extracted, such as in (1) Turner and Schuster (1996) or Fell et al. (2005) for hazard and risk assessments, (2) Stumpf et al. (2011), Michoud et al. (2012) or Tofani (2013) for monitoring techniques, (3) Saito (1969), Fukuzono (1990), Crosta and Agliardi (2003) or Meyer et al. (2012) for slope failure and flow initiation forecasts and (4) Basher (2006) or Dash and Gladwin (2007) for alerts and associated social 
processes. Furthermore, some papers describe how to integrate all tasks together (Angeli et al., 2000; Lacasse and Nadim, 2009). For shallow landslides and debris flows, a huge effort has been performed in order to develop complete and efficient EWSs at regional scales; they are based on rainfall intensity forecasting, soil moisture content and/or antecedent water index, etc. (Keefer et al., 1987; Aleotti, 2004; Baum and Godt, 2010; Jakob et al., 2012; Mercogliano et al., 2013). Nevertheless, it seems that there are only few reviews dealing with practical considerations and specific requirements in order to implement reliable single landslide EWSs that are site-related.

For this purpose, the SafeLand project (2009-2012), funded by the European Commission in the 7th Framework Programme (Grant Agreement No. 226479), intended to develop generic risk management tools and strategies for landslides. Thus, one of its main objectives has been to provide guidelines that would facilitate the establishment of new EWSs and increase the quality of existing systems (Bazin, 2012; Intrieri et al., 2013). Consequently, the first step of this study was to gather experiences from existing EWS strategies and expert judgments. In this way, we prepared a four-page questionnaire that has been filled by 15 institutions in charge of 24 landslide EWSs. Primary analyses were first presented in Bazin (2012). This paper therefore aims to present the results of experiences of those European and North American landslide EWSs, focusing on implementation requirements and potential practical issues of importance for landslide specialists dealing with risk management.

\section{Design of the questionnaire}

As a part of the SafeLand project, a screening study was intended to gather information about the state of the technologies and existing strategies for the establishment of landslide EWSs. A four-page questionnaire was compiled to illustrate the wide spectra of monitoring and integrated platforms, and to merge actual knowledge and expert judgments from existing systems. It aimed to collect information about:

- operational units in charge of the EWS;

- monitored landslide settings and consequences of past events (if any);

- pre-investigations used to design the EWSs;

- monitoring parameters, thresholds and sensors;

- warnings, communication and decision-making processes.
Questions were focused on practical considerations and specific requirements, such as technical challenges in installing and maintaining the EWSs. In addition, it was also oriented towards understanding advantages and disadvantages and revealing the potential lack of existing techniques to propose directions that current research should follow.

In order to maximize the number of potential answers, the questionnaire has been designed to be as short, userfriendly and simple as possible (Lapointe et al., 2010). Indeed, it mainly contained a list of closed questions with preestablished answers clickable in checkboxes. Moreover, a few open questions were also kept in order to leave the compiler free to provide any further considerations and points of view, especially about:

- advantages, limitations and upcoming improvements of current monitoring systems;

- how actual EWSs could be improved.

In practice, units in charge of EWSs often have the responsibility for several landslides, and the questionnaire was therefore designed to fit systems that monitor multiple sites as well as single landslides. The questionnaire was then compiled into a Portable Document Format (pdf) document, one of the most standard formats, in order to ensure that everyone could open and read it. Finally, each user had the possibility to include some supplementary material such as extra text and maps with his answer.

The questionnaire is available in the Supplement.

\section{Results and interpretations}

The questionnaire was sent and spread in June 2011 to about one-hundred institutions in charge of landslide hazard and risk management. These Asian, European and North American institutions were identified within the professional network of SafeLand's participants, national experts and colleagues in the landslide scientific community. The list was also completed by reviewing EWS publications, conferences on landslides and also by looking for internet websites. Finally, in autumn 2011, we received answers from experts belonging to 15 operational units from 9 different countries and related to 24 landslides, i.e., 23 site-specific landslides and 1 regional EWS. Among them, 21 systems are in operation, 1 is under construction and 2 have been stopped. Table 1 sums up the list of institutions (and investigated landslides) that answered the questionnaire. Some slope movements are well known within the landslide community, such as the landslides of Åknes in Norway (Blikra, 2008, 2012; Oppikofer et al., 2009; Jaboyedoff et al., 2011), Ancona (Cotecchia, 2006; Cardellini, 2011) and Ruinon in Italy (Agliardi et al., 2001; Crosta and Agliardi, 2003; Tarchi et al., 2003), Turtle Mountain in Canada (Terzaghi, 1950; Cruden and Krahn, 1973; Benko and Stead, 1998; Froese and Moreno, 2011) and Vallcebre in Spain (Gili et al., 2000; Corominas and Santacana, 


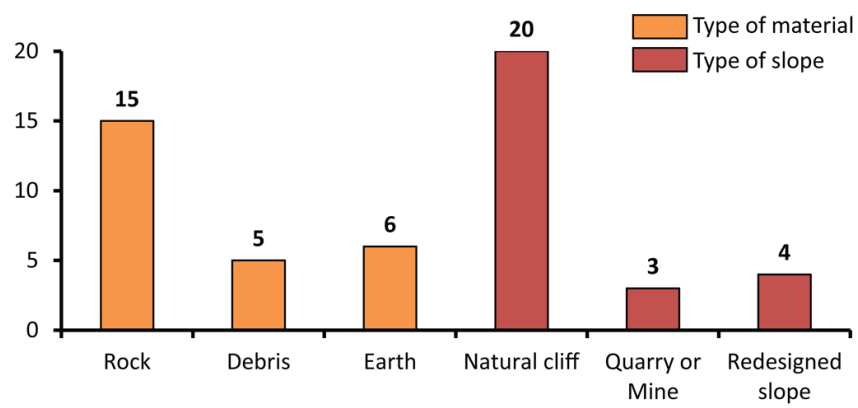

Fig. 1. Type of landslide materials and slopes involved in this study. The total number is over 23 , due to multiple possible settings.

2003; Corominas et al., 2005). On the other hand, the Hong Kong Engineering Office provided the only response dealing with a regional EWS for shallow landslides (Hong Kong Slope Safety, 2012); this case is not included hereafter, since many questions were not designed and thus not applicable for regional systems and also since this singular experience is too different from the other 14 operational units and their 23 related site-specific case studies.

Although 23 answers do not have a high statistical significance, interesting practical trends can still be extracted from the dataset, especially since some of them are among the most studied landslides worldwide, and valuable experiences have thus been accumulated for many years.

\subsection{Units in charge of the EWSs}

The first part of the questionnaire relates to the functioning of operational units. The 14 reported institutions in charge of site-specific landslide monitoring and/or EWSs operate mostly at national and regional level; however, two thirds of them are also responsible for monitoring other natural processes such as weather conditions, volcanoes and/or earthquakes. These units employ especially for their EWSs between 0 (monitoring carried out by universities) and 15 people (IPGP - Martinique). All these institutions are financed by public funds, except one that receives additional private resources. On average, they need about EUR 175000 per year to operate, with a minimum of EUR 60000 for a Czech office in charge of 10 landslides and a maximum of EUR 500000 for the Centro di Monitoraggio Geologico of the ARPA Lombardia in charge of 24 single landslides. However, annual operational costs are highly dependent on the different living standards in each country and also on how the unit is organized; moreover, the funding for replacing and implementing new monitoring systems can highly change from year to year. This highly changing budget and resources from year to year can be a reason why only 7 institutions answered this question.

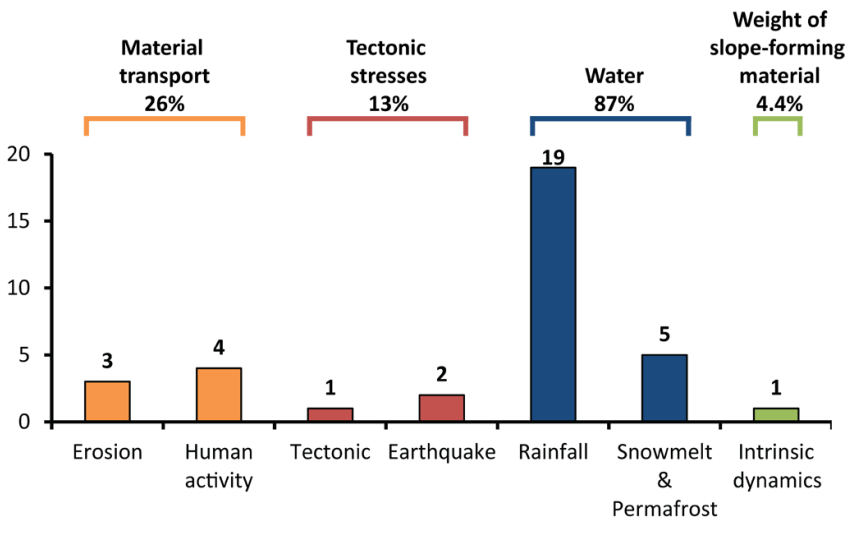

Fig. 2. Triggering mechanisms involved for the 23 reported instabilities and grouped according to Terzaghi's (1950) agents. The total can be over 23 (and $100 \%$ ), since the reported studies can be affected by more than one triggering mechanism.

\subsection{Landslide settings}

\subsubsection{Hazard}

The second part of the questionnaire relates to the context of the 23 monitored instabilities, their previous displacement activities and their potential consequences. It includes a wide range of phenomena (Fig. 1) mostly related to natural slopes, from small rockfalls of less than $10 \mathrm{~m}^{3}$ to large rockslides of more than 50 million $\mathrm{m}^{3}$, or regional debris flows and earth slides. Moreover, landslide events had already occurred for 20 of them.

The studied instability crises are mainly triggered by intensive rainfall (Fig. 2). Snowmelt and permafrost, human activities, erosion processes, tectonic activities, or even their intrinsic dynamics are the other triggering mechanisms sometimes involved. Half of the events happened due to a combination of several factors. Furthermore, classifying triggering factors according to the four physical agents responsible for slope destabilizations described by Terzaghi in 1950 (i.e., material transport, tectonic stresses, water and weight of slope-forming material), water is surely the most important agent, destabilizing more than $87 \%$ of the slopes (Fig. 2).

\subsubsection{Risk}

As introduced before, remediation measures have to be considered when there is an unacceptable risk. Indeed, as shown in Fig. 3, these 23 landslides are directly threatening infrastructures such as roads or railways (for 20 of them), buildings (for 14 of them) and human lives (for 12 of them). Moreover, 8 of them could even lead to significant indirect consequences, such as tsunami induced by rockslides (Blikra, 2008, 2012; L'Heureux et al., 2011) or outbursts resulting from landslide dam failures (Costa and Schuster, 1988; Korup, 2002). In the past, the 20 reported landslides that are now active or dormant (cf. the classification of 
Table 1. Exhaustive list of the monitored landslides and their related operational units that answered the questionnaire during summer 2011.

\begin{tabular}{|c|c|c|}
\hline Country & Operational unit & Monitored landslide \\
\hline \multirow[t]{2}{*}{ Canada } & Alberta Geological Survey & Turtle Mountain $^{\mathrm{a}}$ \\
\hline & University of Laval & Gascon Rockslide ${ }^{b}$ \\
\hline \multirow[t]{2}{*}{ Czech Republic } & Geo-Tools & unnamed $^{\mathrm{a}}$ \\
\hline & National Park Bohemian Switzerland & Hrensko $^{\mathrm{a}}$ \\
\hline \multirow[t]{2}{*}{ France } & Service de Restauration des Terrains en Montagne & La Valette ${ }^{\mathrm{a}}$ \\
\hline & Institut de Physique du Globe de Paris à la Martinique & Prêcheur River ${ }^{\mathrm{c}}$ \\
\hline China & Geotechnical Engineering Office & Entire Hong Kong province ${ }^{a, x}$ \\
\hline \multirow[t]{9}{*}{ Italy } & Ancona Monitoring Center & Ancona $^{\mathrm{a}}$ \\
\hline & Centro di Monitoraggio Geologico - ARPA Lombardia & Ruinon $^{\mathrm{a}}$ \\
\hline & Servizio Geologico Aosta & Becca di Nona ${ }^{a}$ \\
\hline & & Bosmatto $^{\mathrm{a}}$ \\
\hline & & Chervaz $^{\mathrm{a}}$ \\
\hline & & Citrin $^{\mathrm{a}}$ \\
\hline & & La Saxe $^{\mathrm{a}}$ \\
\hline & & Vollein $^{\mathrm{a}}$ \\
\hline & Università degli Studi di Firenze & Torgiovannetto $^{c}$ \\
\hline \multirow[t]{5}{*}{ Norway } & Åknes/Tafjord Early warning Centre & Åknes ${ }^{\mathrm{a}}$ \\
\hline & & Hegguraksla $^{a}$ \\
\hline & & Jettan $^{\mathrm{a}}$ \\
\hline & & Mannen $^{\mathrm{a}}$ \\
\hline & Nebbet Monitoring Center & Nebbet Mountain ${ }^{a}$ \\
\hline \multirow[t]{2}{*}{ Slovakia } & State Geological Institute of Diunyz Stur & Okolicne $^{\mathrm{a}}$ \\
\hline & & Velka Causa $^{\mathrm{a}}$ \\
\hline Spain & Universitat Politècnica de Catalunya & Vallcebre $^{\mathrm{a}}$ \\
\hline
\end{tabular}



Fig. 3. Number of landslides that are endangering buildings, transportation infrastructures and people, and creating indirect risks or even other issues. The total number is over 23 , because consequences of a landslide can affect more than a single target.

Cruden and Varnes, 1996) produced considerable economic losses that are difficult to quantify (even if estimated at about EUR 400 million by their operational units). Furthermore, they had important social consequences, destroying roads and villages, isolating populations and even killing more than 110 people. For example, the rock avalanche at Turtle
Mountain in 1903 buried more than 70 citizens of the village of Frank during their sleep (McConnell and Brock, 1904). In 1934, the Hegguraksla rockslide indirectly killed 40 people due to the landslide-induced tsunami that destroyed several villages along the fjord with a wave reaching a maximum height of 62 ma.s.l. (Kaldhol and Kolderup, 1936; Bugge, 1937).

For 10 of the reported landslides, some physical mitigation works were performed to prevent new catastrophic events, such as retaining basins for debris flows or retaining walls for rockfalls when the context allowed it. Moreover, revision of the land-use plans has been implemented in the hazard zones for almost $75 \%$ of the reported landslides, essentially updating land-use restrictions and construction norms for new inhabitants and infrastructures to reduce the number of elements at risk, their vulnerability and/or the population exposition.

\subsubsection{Pre-investigations for EWSs}

The third part of the questionnaire was related to investigations performed before the design of the monitoring systems. 


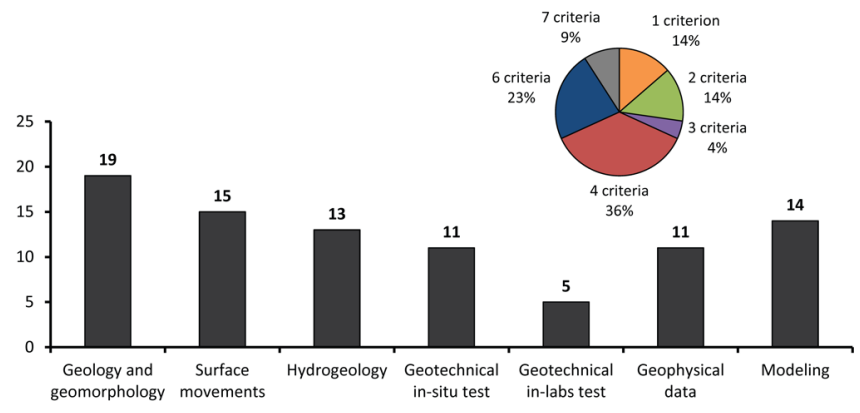

Fig. 4. Inventory of investigations performed before designing the 23 reported EWSs performed and percentage of total number of criteria investigated per site. The total number of investigations is over 23 , because $86 \%$ of the landslides required more than one type of criterion.

Several issues are usually investigated in order to get a sufficient understanding of the unstable systems, which is required for designing a proper and pertinent monitoring network (Fig. 4).

The most investigated criteria are obviously the landslide geology and the geomorphology (for 19 of them), completed by surface movement data (for 14 of them). Indeed, geological and geomorphological studies are crucial for understanding unstable slope behavior and for providing relevant conceptual models. This includes mapping of landslide features (e.g., main and minor scarps, open fractures, surfaces of rupture and compression zones) and evidence of recent activities. Furthermore, investigating surface and sub-surface displacements is often crucial for making reliable landslide conceptual models. The coupling of geological, geomorphological and displacement maps is an important foundation for designing monitoring networks and sensor locations. The monitoring network of the Norwegian rockslide in Mannen (Fig. 5) illustrates how a monitoring network can be designed, with in-place instrumentations in the accessible upper areas close to the open fractures, and with ground-based remote-sensing techniques to cope with less accessible lower parts. Moreover, sub-surface monitoring in deep boreholes is performed at two accessible localities in order to fulfill the Norwegian requirements for EWSs.

In addition, numerical models are computed for 14 instabilities in order to (1) determine stability factors and (2) map potential run-out areas of rockfalls, rock avalanches, debris flows, as well as rockslide-induced tsunamis. Therefore, simulation models are essential for identifying exposed populations and infrastructures. Geophysical measurements (mainly seismic refraction and electrical resistivity) and geotechnical in situ tests (such as standard or cone penetration tests) are performed in approximately $50 \%$ of the cases, providing useful complementary information on subsurface conditions. Geotechnical in-lab tests are usually less employed than other criteria.
Surprisingly, hydrogeological conditions are only investigated for half of the cases (mainly piezometers and/or rain gauges). It contrasts with the fact that in the $2 \mathrm{nd}$ part of the questionnaire, water is considered as a physical destabilizing agent for $87 \%$ of the reported instabilities (Fig. 2), and groundwater conditions are also required for reliable landslide models. For example, Bonnard and Steiger (2012) advise a minimum of two years of water-table monitoring before designing any drainage systems.

Finally, it is also important to note the common use of a multi-criteria approach. Thus, as seen in Fig. 4, operational units have designed their EWS on 4 types of criteria and even more in $69 \%$ of the cases. The use of only one criterion is a method used for $14 \%$ of the cases, and this is mostly implemented for cases where debris flows are triggered by heavy precipitations.

\subsection{Monitoring systems}

\subsubsection{Sensor network}

The fourth part of the questionnaire relates to instruments and sensors used to monitor the instabilities. Two of our partners, monitoring fragmental rockfall events, reported difficulties in filling this section table to us because of its pdf format; the following interpretations are thus based on the other 21 case studies. Figure 6 displays the different types of observed parameters and Fig. 7 sums up the different setup sensors. Detailed theoretical and technical aspects on all these landslide monitoring sensors are developed in Stumpf et al. (2011) and Michoud et al. (2012).

The large majority of the EWSs is based on the monitoring of surface and sub-surface displacements (for 18 of them), certainly because they show direct evidence of active deformations. In order to measure movements, half of the networks are based on extensometers and/or Global Navigation Satellite Systems (GNSS); crackmeters and inclinometers are also frequently used. These sensors deliver reliable data and are robust and cheap (except for GNSS). Regarding GNSS, even if antennas and receivers are more expensive than other systems and the data processing more complicated, they have the major advantage that they provide 3-D displacement information. Other techniques such as groundbased interferometric radar (GB-InSAR), total station, laser, or tiltmeters are less used. Up to now they were considered to be expensive as well as to create some difficulties related to setup and data processing in comparison with other methods. Furthermore, some instruments such as crackmeters or GB-InSAR may become fragile in harsh environments, and good protection (against heavy rainfall, snow load or snow creep for example) has to be considered to protect them. Sub-surface monitoring in boreholes is common in some of the largest and more complex landslides, and is used in 6 of the reported cases. Several of the landslide monitoring systems have now changed the instrumentation from traditional 




Fig. 5. Mannen rockslide monitoring network. Ground-based in-place instrumentation is concentrated close to the back scarp, while the GB InSAR system is placed in the valley below. Two deep boreholes are instrumented by $120 \mathrm{~m}$-long DMS columns. Open fractures and slide scars were identified and mapped during previous field investigations. Theoretical and technical details of those techniques are developed in Stumpf et al. (2011) and Michoud et al. (2012).



Fig. 6. Inventory of monitored parameter types for the 21 reported monitoring networks. The total number is over 21 , because more than one parameter is monitored for 15 of the landslides.

manual inclinometric probe measurements to automatic and long columns, such as the DMS system (Lovisolo et al., 2003), consisting of a large number of sensors managing to monitor continuous sequences.

It is also interesting to note that the Turtle Mountain and Åknes instabilities are monitored using spaceborne radar interferometry (InSAR) techniques as well. Even if it does not provide real-time data and de facto cannot be used for operative early warnings, it is a useful approach to understand and update the landslide dynamics using images from space agencies' archives. Moreover, Spaceborne InSAR can be helpful during pre-investigation work and can also provide EWSs with complementary information. Indeed, an overview of the regional stability in the neighborhood of the monitored slopes is important in many cases, since large landslides as sackungs are able to destabilize small monitored landslides inside the large deformed masses (Agliardi et al., 2001).

In addition to displacement data, meteorological parameters are crucial to be monitored, since rainfall, snowmelt and permafrost are considered as a triggering factor for $20(87 \%)$ of the instabilities (Fig. 2). Meteorological parameters are thus very frequently measured (in 14 EWSs) as well as water table levels and water discharge in streams (in 9 EWSs); indeed, rain gauges are included in half of the monitoring networks, and piezometers and temperature gauges in 7 of them. 


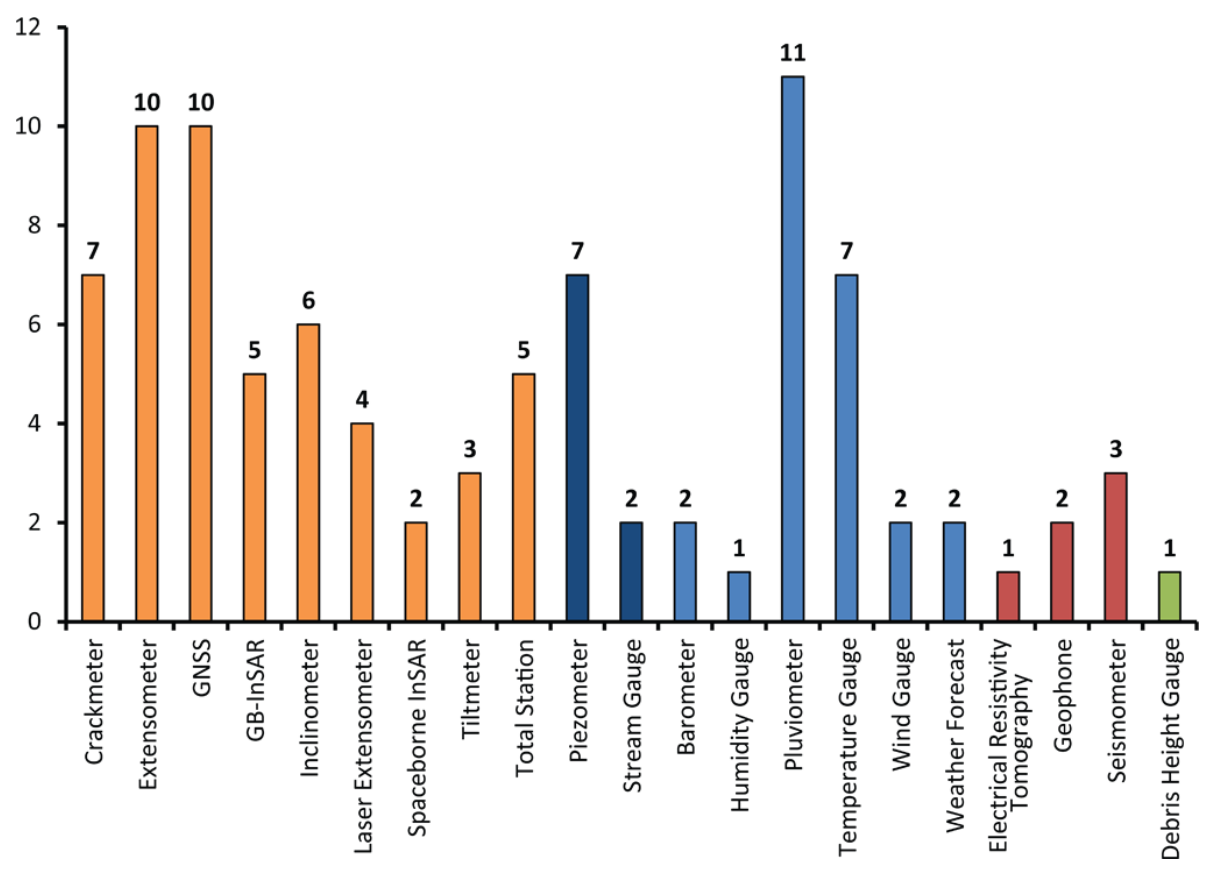

Fig. 7. Inventory of the different techniques used for the 21 reported monitoring networks in order to measure surface and sub-surface displacements (in orange), water and groundwater table levels (in dark blue), weather conditions (in light blue), geophysical properties (in red) and available sediment volumes (in light green). Theoretical and technical details of those techniques are developed in Stumpf et al. (2011) and Michoud et al. (2012).

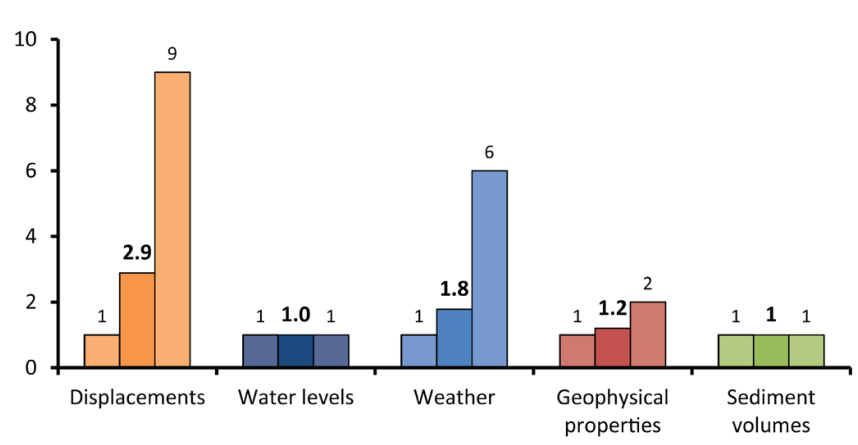

Fig. 8. Minimum, mean and maximum instrument types used to monitor each parameter (when it is done) per landslide.

Near-surface geophysical methods have been considerably improved during the last two decades, and their uses for landslide investigation purposes have been reviewed in Jongmans and Garambois (2007). Nevertheless, geophysical applications for operational EWSs are still under development (Spillman et al., 2007; Roth, 2012; Mainsant et al., 2012; Navratil et al., 2013), largely explaining why they are applied for only 5 of the 21 reported case studies.

An EWS implemented in debris and earthflow source areas also monitors the volume of available sediments that can be mobilized in case of heavy rainfall, using gauges that measure the sediment heights in order to be able to forecast potential event intensities.
Redundancy is important in EWSs (Figs. 8 and 9). This is particularly evident for robust monitoring networks that measure displacements and groundwater. For example, in the Åknes instability, displacements are monitored by 8 instrument types: 8 crackmeters, 8 GNSS antennas, 2 laser devices, 1 ground-based radar, 3 extensometers, 1 total station coupled with 30 prisms, 2 surface tiltmeters and 3 deep boreholes instrumentated with inclinometers and water-pressure measurement cells (DMS columns). It allows one to (1) monitor several sectors with different dynamics and displacement rates on the surface and the sub-surface, (2) discriminate unwanted false alarms coming from large noise or one defective sensor and (3) have instruments fed by several power supply and data communication lines. On the contrary, only one meteorological station (e.g., with rainfall, temperature, snow depth or humidity gauges) is usually installed to monitor weather conditions, since landslides are usually confined to small areas with relatively similar conditions.

In conclusion, based on the experiences of the reported institutions in charge of landslide EWSs, a good monitoring network is characterized by:

1. simplicity;

2. robustness;

3. presence of multiple sensors;

4. power and communication lines backups (detailed in Sect. 3.3.2). 


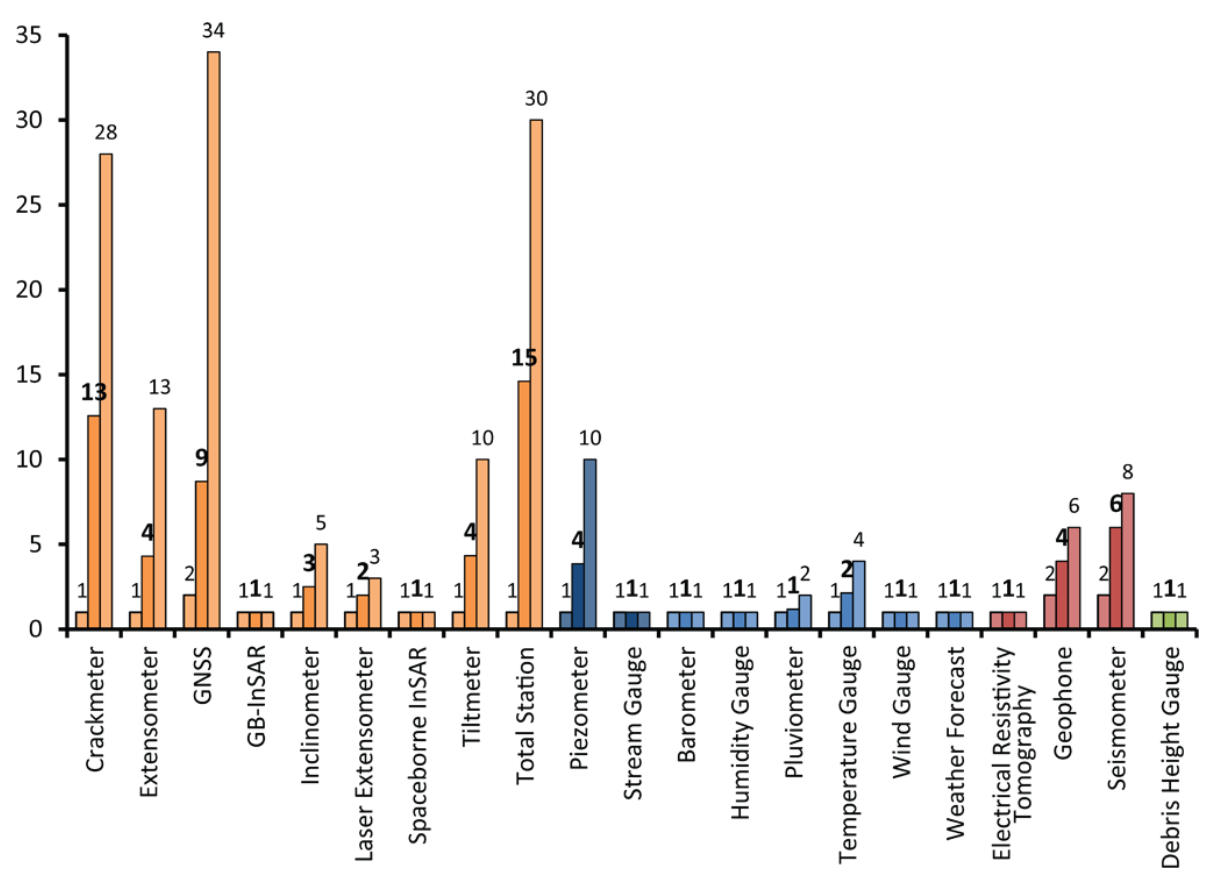

Fig. 9. Minimum, mean and maximum number of sensors of each type per landslide, when used, in order to monitor surface and sub-surface displacements (in orange), water and groundwater table levels (in dark blue), weather conditions (in light blue), geophysical properties (in red) and available sediment volumes (in light green). Theoretical and technical details of those techniques are developed in Stumpf et al. (2011) and Michoud et al. (2012).

The following characteristics are also important for the choice of instrumentation:

1. implication for understanding the landslide evolution;

2. high life expectancy;

3. robustness;

4. price;

5. level of real-time data;

6. noise level of the sensors.

On the other hand, a system is limited if it is based only on surface displacements and if it can be damaged by weather conditions and/or landslide events themselves before sending data or alarms to the operational center. Present monitoring networks can still be improved by a better integration and near real-time compilation of all monitoring data, for example by coupling displacements with weather conditions, groundwater and/or seismic activities.

\subsubsection{Power and data management networks}

The principle of redundancy is also important for power and data management networks, as shown in detail in Froese and Moreno (2011). Those networks supply monitoring sensors with electricity, and allow manual remote data access for experts' periodic checks and automatic data transmission to operational units based on Internet protocols. Regarding the 23 reported sites, two thirds of monitoring networks are equipped with power supplies, communication lines and systems backups for monitoring sensors and for operational centers, in order to ensure continuous data measurement, transmission and analysis.

\subsubsection{Alarms}

The fifth and last part of the questionnaire is focused on the way to use monitored data, establishing alarms and associated responses to protect endangered populations and infrastructures.

Threshold values for alarm messages are normally based on the evaluation of different sensors and an expert interpretation of the stability conditions, mainly during the pre-investigation work (Blikra, 2008; Froese and Moreno, 2011). Because they are direct evidence of activity, almost all threshold parameters are based on displacement data (for 13 of the 15 reported answers), sometimes coupled with rainfall data (for 6 cases). More rarely, 2 earthslides in Slovakia use the groundwater table level monitored by piezometers as a threshold parameter.

Figure 10 highlights essential characteristics for the establishment of alarm procedures. In order to limit false alarms, threshold values are based on multiple identical devices and/or several redundant types of sensor for 19 of the EWSs. 


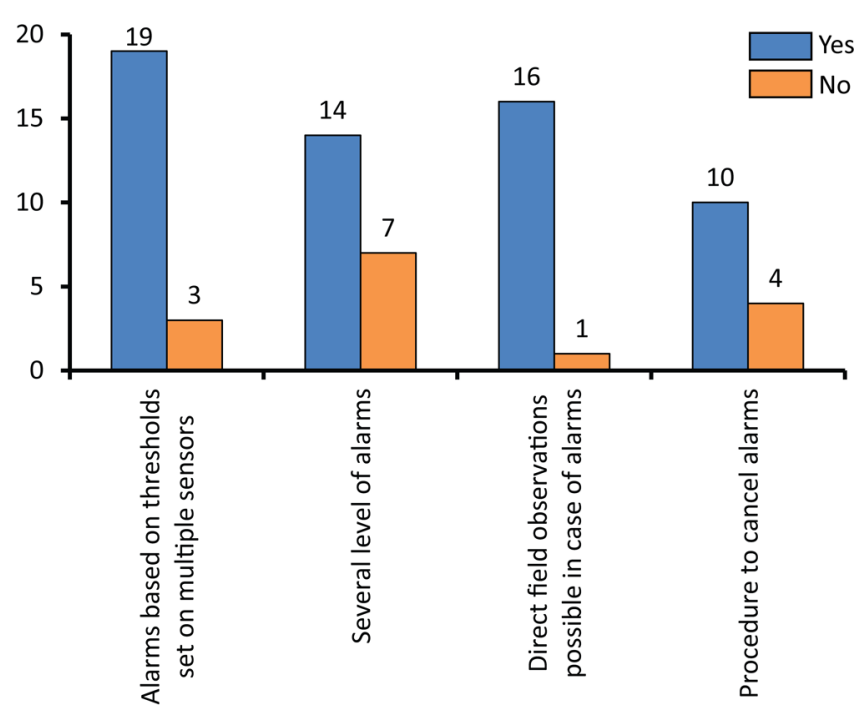

Fig. 10. Inventory of the essential characteristics of alarm procedures for the 23 reported monitoring networks.

Curiously however, only 9 of the threshold values take technical sensor limitations such as the smallest detectable signal and noise levels into account before establishing them, even if it allows the alarm's reliability to be increased. Furthermore, several levels of alarms (such as Table 2) have been established for one third of the reported systems.

As soon as a threshold value is reached by a predefined number of sensors, 22 of the 23 monitoring networks automatically send an alarm message to an operator on call 24/7. The most used communication technique is largely an automatic SMS sent to cellular operators and is too rarely coupled with other redundant systems such as emails or voice phone messages (Fig. 11). These alarms prompt the person on duty to inspect the monitored data. Moreover, direct field observations are possible in many cases to get additional information about the stability conditions, especially during critical stages, by checking visible changes such as local activities (e.g., sliding and/or falls) within the whole landslide area. Finally, according to expert judgments based on the monitored data and these field observations, procedures to manually cancel alarms have been established for two thirds of the reported case studies.

\subsection{Dealing with populations}

\subsubsection{Decision-making processes}

Tailored strategies have to be adopted depending on the landslide state of activity, and two thirds of the reported EWSs have established different thresholds for different scenarios. For example, the Emergency Preparedness Centre in Stranda established gradual alert postures based on different threshold values and expert evaluations, leading to appropriate responses such as the evacuation of endangered populations

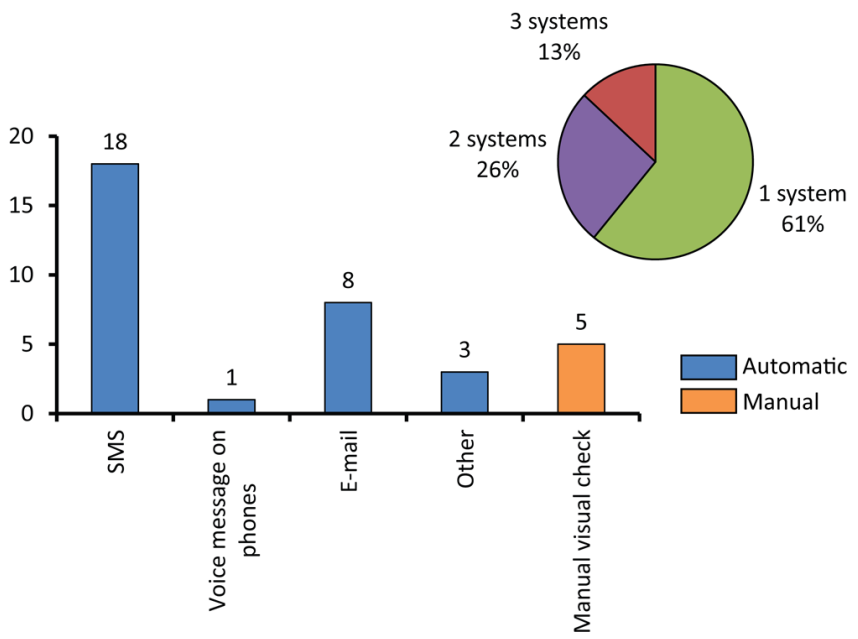

Fig. 11. Inventory of automatic and manual techniques used to send alarms from the monitoring network to the operational unit and percentage of number of techniques used simultaneously for the 23 reported monitoring networks. The total number is above 23 , since $39 \%$ of the monitoring networks use more than one technique.

(Table 2). The execution of these strategies requires close collaboration between the operational units and local and/or regional authorities. Rigorous protocols have to be established in order to clearly define the roles and responsibilities of each institution according to the alert levels; a detailed example of the Turtle Mountain Monitoring Project protocols is illustrated in Moreno and Froese (2009). The flowchart is a common representation that gives an evident checklist reviewing necessary procedures, as shown for instance in Fig. 12.

The design of decision-making processes should take care of legislation and cultural issues, as well as of the prerogatives of the involved agencies. Three fourths of the reported strategies have been designed by the operational units, with the help for about one third of them from local authorities and/or regional and governmental institutions (Fig. 13). Moreover, the procedures have almost all been reviewed by operational checklists (in 16 cases), completed in 8 cases by reviews from external groups.

\subsubsection{Alert broadcasts}

When circumstances require the evacuation of local populations, the most used communication vectors to inform people are radio, siren and SMS, coupled sometimes with telephone and television (Fig. 14); however, normal evacuation approaches by policemen walking door-to-door are also important routines. Websites and e-mails are rarely used, since it is not sure that they manage to reach the population in time for imminent danger. Regarding the closing of road sections, the most frequent system is simple traffic lights that can actually be completed by policemen. According to our ability to predict in advance the time to slope failure or to 
Table 2. Example from the Emergency Preparedness Centre in Stranda (Norway) of gradual alert levels based on different threshold values and expert evaluations leading to planned responses (modified from Blikra et al., 2007).

\begin{tabular}{|c|c|c|c|}
\hline $\begin{array}{l}\text { Velocities } \\
{\left[\mathrm{mm} \mathrm{day}^{-1}\right]}\end{array}$ & Alarm level & $\begin{array}{l}\text { Activities } \\
\text { and alarms }\end{array}$ & Response \\
\hline $0.1-0.5$ & $\begin{array}{l}\text { Level } 1 \text { - Green } \\
\text { Normal situation }\end{array}$ & $\begin{array}{l}\text { Minor seasonal variations } \\
\text { No alarm }\end{array}$ & $\begin{array}{l}\text { Technical maintenance } \\
\text { EPC staff }\end{array}$ \\
\hline $0.5-2$ & $\begin{array}{l}\text { Level } 2 \text { - Blue } \\
\text { Awareness }\end{array}$ & $\begin{array}{l}\text { Important seasonal fluctuations for indi- } \\
\text { vidual and multiple sensors } \\
\text { Values < excess thresholds for Level } 2\end{array}$ & $\begin{array}{l}\text { Increase frequency of data review and } \\
\text { comparison of different sensors } \\
\text { EPC staff }\end{array}$ \\
\hline $2-5$ & $\begin{array}{l}\text { Level } 3 \text { - Yellow } \\
\text { Increase awareness }\end{array}$ & $\begin{array}{l}\text { Increased displacement velocity, seen on } \\
\text { several individual sensors } \\
\text { Values < excess thresholds for Level } 3\end{array}$ & $\begin{array}{l}\text { Do continuous reviews and field survey } \\
\text { Geo-expert team at EPC full time } \\
\text { Inform police and emergency prepared- } \\
\text { ness teams in municipalities }\end{array}$ \\
\hline $5-10$ & $\begin{array}{l}\text { Level } 4 \text { - Orange } \\
\text { High hazard }\end{array}$ & $\begin{array}{l}\text { Acceleration in displacement velocity } \\
\text { observed on multiple sensors } \\
\text { Values < excess thresholds for Level } 4\end{array}$ & $\begin{array}{l}\text { Increase preparedness, continuous data } \\
\text { analysis } \\
\text { Alert municipalities to stand prepared for } \\
\text { evacuation }\end{array}$ \\
\hline$>10$ & $\begin{array}{l}\text { Level } 5 \text { - Red } \\
\text { Critical situation }\end{array}$ & $\begin{array}{l}\text { Further acceleration } \\
\text { Values > excess thresholds for Level } 4\end{array}$ & Evacuation \\
\hline
\end{tabular}

flow initiation (Fukuzono, 1990; Crosta and Agliardi, 2003; Baum and Godt, 2010; Federico et al., 2012; Meyer et al., 2012) and the stakes of each site, reaction times after warning are from $10 \mathrm{~min}$ to close roads, as in Torgiovanetto, to $72 \mathrm{~h}$ to evacuate populations, as for Norwegian rockslides.

Prior to real evacuations, operational units and local units have imperatively to ensure that the public has been well informed about the adopted strategies, in order to guarantee that the plan comes together with proper cooperation and behavior of the local populations (as detailed in Sect. 3.4.3). In addition, evacuation exercises, which have been performed once or twice for 12 reported case studies, have recently turned out to be necessary for testing the efficiency of established plans and procedures (Moreno and Froese, 2009).

\subsubsection{Risk communications}

The trust of local populations in EWSs and proper risk perception are fundamental to the success of an EWS (Dash and Gladwin, 2007), since cooperative and collective actions are required in case of alerts. Due to socio-cultural heritages, fair judgments need openness, involvement and good consultation processes. Ostrom (1998) further recommends faceto-face communication. It provides the best positive effects on cooperative tasks, allowing, among other things, the exchange of mutual commitments and the assurance of proper expectations of population behaviors in case of evacuation, for instance. For half of the reported cases, the information is given thanks to public meetings, reports, as well as websites (Fig. 15). Other solutions, such as newspapers, are still anecdotal. No answers referred to any information provided by TV programs. Good risk communication also means that public meetings have to be organized to inform and consult local populations during and/or after every round of the decision-making process.
Finally, a last point is also clear: monitoring centers are in charge of sensitive and complex data. Indeed, even if they are all partially or totally financed by public funds, two thirds of the institutions still do not provide free and easy access to data for anyone. It can be also a question about letting the public have access to raw data that can be difficult to interpret due to noise in the sensor measurements. Although not communicating the monitored data could make local people suspicious, incorrect readings could also certainly lead to major misunderstandings and unnecessary concerns (Mileti and Sorensen, 1990). Therefore, the right communication level is difficult to reach.

\subsection{Practical challenges}

The last part of the questionnaire relates to practical challenges encountered during the design, the construction and the maintenance of the EWSs (Fig. 16). Most of them (20) related some problems during the installation and the maintenance of the sensors. Indeed, more than half of the instrumentation deals with harsh weather and site conditions, suffering from heavy rainfall, ice, thick snow cover, avalanches, wind, etc. On the other hand, funding and human resources are sources of problems for less than one third of the EWSs.

Of the 8 participating countries, only Norway legislated on EWS in order to define the roles of institutions in charge of landslide EWSs and to direct them (technical requirements in the Norwegian building codes). In addition, Slovakia produced a guideline about general strategies to adopt and Canada is on the way (Couture et al., 2012). As a consequence, the operational units in charge of EWSs have to look for scientific and practical support from other expert groups and/or international experience. 




Fig. 12. Flowchart of the protocol that has to be followed in case of alarm in Ancona, Italy (modified after Cardellini, 2011).

\section{Discussions and conclusions}

This paper aims to present some reflections for implementing site-specific landslide EWSs, focusing on specific requirements and practical issues based on current ongoing experiences. A questionnaire on these purposes was created and sent to about one-hundred institutions in charge of landslide management. About one fourth of the requests received an answer. One reason could be the lack of availability of the persons in charge. Another reason could be the questionnaire format (a pdf file including questions and tables sent by emails), even if it seemed to be easily accessible for everybody. Several institutions indeed reported difficulties in filling some parts of the questionnaire to us, and had to print it to write answers by hand. For future investigations, we would recommend the use of interactive web-based survey



Fig. 13. Inventory of institutions involved in the establishment of strategies in case of alerts and percentage of number of institutions involved together for the 23 reported EWSs. The total number is above 22 , because $36 \%$ of the strategies have been designed by more than one institute.

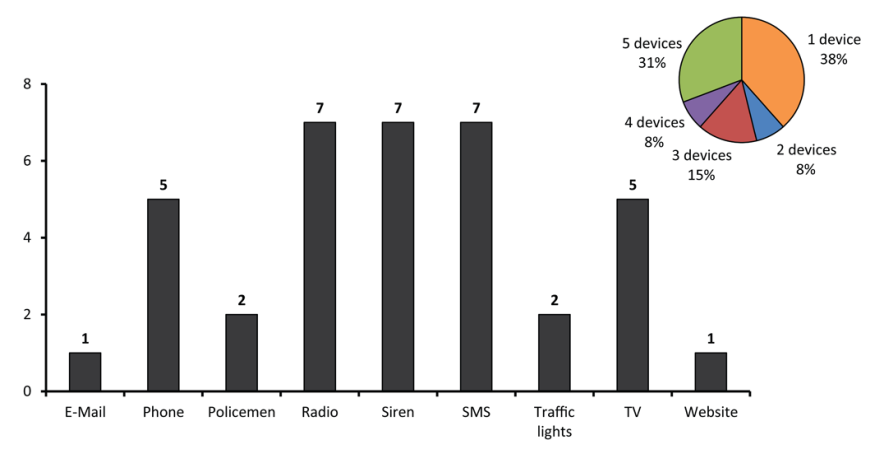

Fig. 14. Inventory of the different ways used to issue the alerts to local populations and percentage of number of communication devices coupled for the 13 reported answers got from questionnaires. The total number of communication vectors for alerts is over 13, because $38 \%$ of the systems use more than one type of device.

tools (e.g., as in Tofani et al., 2013); they are indeed more user-friendly to fill by respondents (maximizing the number of potential answers as shown in Lapointe et al., 2010) and also to analyze afterwards. Although the small number of answers does not have a high statistical significance, several of the reported EWSs are among the most studied landslides in Western countries. They have also accumulated high-quality knowledge after many constructive studies and experiments; valuable results and future recommendation can thus be extracted from these sites.

There are no standard requirements for designing and operating EWSs. Actually, we cannot provide solutions to all questions, since every situation is unique, depending on landslide hazard and risk settings, local legislations and available resources. Such guidelines are provided in a comprehensive report (Bazin, 2012). Nevertheless, this review based on current experiences highlights specific requirements and potential practical issues that operational units would have to take into consideration when designing their system: 


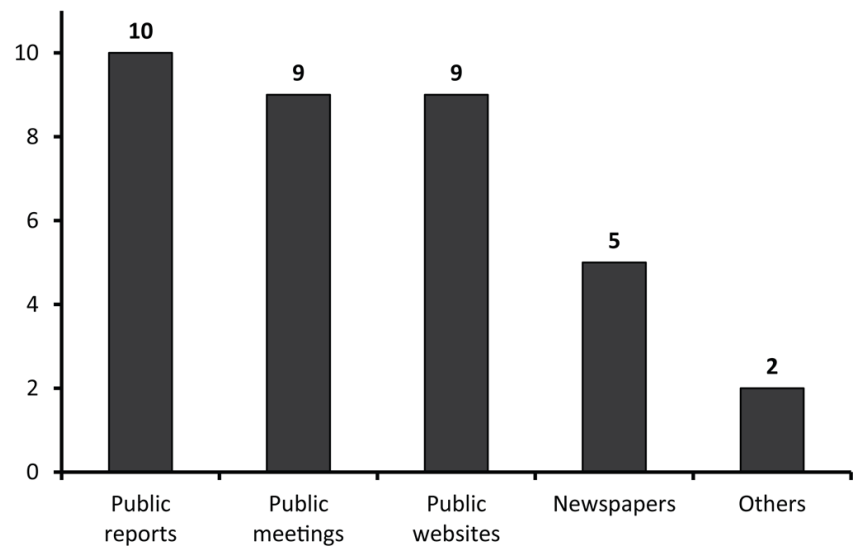

Fig. 15. Inventory of communication vectors used to inform local populations for the 23 reported EWSs. The total number of vectors is over 23, because several institutions communicated in several ways.

- it is crucial to acquire a proper understanding of instabilities through hazard and risk pre-investigations, and to constantly update landslide conceptual models with the newer monitored data of EWSs;

- redundancy, simplicity, robustness, communication and power supply backups are necessary for a reliable monitoring system. This should support a near realtime interpretation of the stability conditions by experts;

- the establishment of different scenarios adapted to gradual increasing of alert levels based on reliable landslide models is important. Procedures should clearly define the role and the responsibilities of all involved institutions. Alerts should be as quick and as direct as possible;

- public meetings for properly informing and consulting local populations are important in order to ensure a trust atmosphere and appropriate behavior of people in case of alert.

Nevertheless, some EWSs are limited by theoretical and practical issues that are currently being investigated:

- First, operational units also underline that, most of the time, monitoring networks are located in harsh conditions and therefore that it is difficult to install and maintain sensors. This point emphasizes the importance for manufacturers to improve long-term sensor robustness and for operational units to ensure a proper maintenance budget.

- EWSs could be significantly improved by current research, focusing on a better near real-time integration of monitoring data from different sensor types

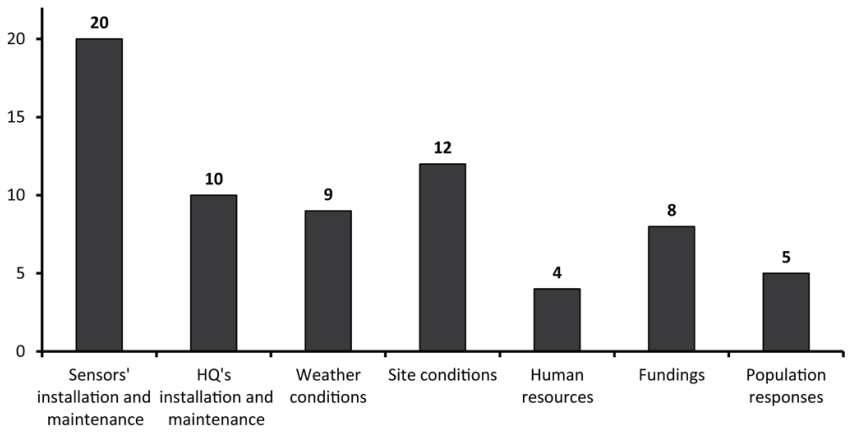

Fig. 16. Inventory of practical challenges met by the 23 reported EWSs. The total number of challenges is over 23, because EWSs usually encountered more than one issue during their life cycles.

(Bichler et al., 2004; Travelletti et al., 2012; Michoud et al., 2013). Sensors and their data processing are undergoing fast development (Tofani et al., 2012), getting to the continuous integration of GB-InSAR data (Casagli et al., 2010; Chantry et al., 2013; Montserrat et al., 2013), LiDAR data (Riegl, 2013) and geophysical measurements (Mainsant et al., 2012; Navratil et al., 2013) to monitor landslides. Due to this fast evolution, monitoring systems have to be regularly updated, having once again an impact on EWS deployments and maintenance costs (Froese, 2013).

- In addition to technical limitations, this survey also highlights some EWS conceptual issues. For instance, it seems there is a lack of investigations into hydrological factors in landslide processes, since water is involved in about $86 \%$ of slope destabilizations and/or landslide triggering, but is investigated with rain gauges or piezometers for only half of the cases.

- Moreover, an important challenge is to improve the reliability and pertinence of automatic alarms in the future. Surprisingly, about half of the reported systems did not take into consideration technical sensor limitations before establishing threshold values, even if it would surely decrease the frequency of false alarms. In addition, recent research is focused on failure forecasting and/or flow initiations by looking for mass movement indicators (Baroň et al., 2012) such as precursory displacements (Abellán et al., 2010; Federico et al., 2012), changes in slope rheological settings (Mainsant et al., 2013), strain rates (Jaboyedoff et al., 2012), or hydrological conditions (Abellán et al., 2013; Mercogliano et al., 2013).

We can also add that a recent workshop ("The 1st International Workshop on Warning Criteria for Actives Slides"), held in Courmayeur, Italy, during the review process of this paper (10-12 June 2013), showed one additional issue. After a decade of service, it indeed seems that some EWSs need to 
be redeployed because of low activity of the landslides and budget issues. This leads to learning how to go from expensive and complex EWS to simpler and cheaper monitoring systems (Troisi and Negro, 2013; Froese, 2013).

Finally, the collected feedback and experiences, in addition to current research, will therefore contribute to modifying and improving existing and future EWS strategies.

\section{Supplementary material related to this article is available online at \\ http://www.nat-hazards-earth-syst-sci.net/13/2659/2013/ nhess-13-2659-2013-supplement.pdf.}

Acknowledgements. The present work has been partially supported by the SafeLand "Living with landslide risk in Europe: Assessment, effects of global change, and risk management strategies" project (7th Framework Programme of the European Commission, Grant Agreement No. 226479). This support is gratefully acknowledged. We would also like to thank our SafeLand partners, and more particularly Ivo Baroň, for their essential and appreciated support. Thanks also to Marie Charrière, who recommended valuable references on risk communication. Moreover, Veronica Tofani, Simone Frigerio and Emanuele Intrieri helped us to significantly improve the present document thanks to pertinent remarks and suggestions. Finally, we thank all the institutions that responded to the screening study.

Edited by: V. Tofani

Reviewed by: E. Intrieri and S. Frigerio

\section{References}

Abellán, A., Calvet, J., Vilaplana, J. M., and Blanchard, J.: Detection and spatial prediction of rockfalls by means of terrestrial laser scanner monitoring, Geomorphology, 119, 162-171, 2010.

Abellán, A., Moya, J., Jaboyedoff, M., and Corominas, J.: Prediccion de la velocisas de un deslizamiento en base a la precipitación, Applicación en la zona de studio piloto de Vallcebre (Pirineos Catalanes), in: Proceedings of the VII Simposio Nacional sobre Taludes y Laderas Inestables, Palma de Mallorca, Spain, 11-14 June 2013, 1081-1092, 2013 (in Spanish).

Agliardi, F., Crosta, G. B., and Zanchi, A.: Structural constraints on deep-seated slope deformation kinematics, Eng. Geol., 59, 83102, 2001.

Aleotti, P: A warning system for rainfall-induced shallow failures, Eng. Geol., 73, 247-265, 2004.

Angeli, M.-G., Pasuto, A., and Silvano, S.: A critical review of landslide monitoring experiences, Eng. Geol., 55, 133-147, 2000.

Baroň, I., Supper, R., and Ottowitz, D. (Eds.): SafeLand deliverable 4.6.: Report on evaluation of mass movement indicators, European Project SafeLand, Grant Agreement No. 226479, 382 pp., available at: http://www.safeland-fp7.eu, 2012.

Basher, R.: Global early warning systems for natural hazards: systematic and people-centered, Phil. Trans. R. Soc., 364, 21672182, 2006.
Baum, R. L. and Godt, J. W.: Early warning of rainfall-induced shallow landslides and debris flows in the USA, Landslides, 7, 259272, 2010.

Bazin, S. (Ed.): SafeLand deliverable 4.8.: Guidelines for landslide monitoring and early warning systems in Europe - Design and required technology, European Project SafeLand, Grant Agreement No. 226479, 153 pp., available at: http://www.safeland-fp7. eu, 2012.

Benko, B. and Stead, D.: The Frank Slide: A reexamination of the failure mechanism, Can. Geotech. J., 35, 299-311, 1998.

Bichler, A., Bobrowsky, P., Best, M., Douma, M., Hunter, J., Calvert, T., and Burns, R.: Three-dimensional mapping of a landslide using a multi-geophysical approach: the Quesnel Forks landslide, Landslides, 1, 29-40, 2004.

Blikra, L. H.: The Åknes rockslide: Monitoring, threshold values and early-warning, in: Landslides and Engineering Slopes: From the Past to the Future, Proceedings of the 10th International Symposium on Landslides and Engineering Slopes, Xi' an, China, 30 June-4 July 2008, 1089-1094, 2008.

Blikra, L. H.: The Åknes rockslide, Norway, in: Landslides: Types, Mechanisms and Modeling, edited by: Clague, J.J. and Stead, D., Cambridge, 323-335, 2012.

Bonnard, C. and Steiger, H.: Control of an unstable slope by horizontal drainage boreholes and soil nailing during the widening of a major road, Laubegg gorge Switzerland, in: Landslides and Engineering Slopes: Protecting Society through Improved Understanding, Proceedings of the 11th International and 2nd North American Symposium on Landslides and Engineered Slopes, Banff, Canada, 3-8 June 2012, 1575-1580, 2012.

Bugge, A.: Fjellskred fra topografisk og geologisk synspunkt, Norsk Geografisk Tidsskrift, 6, 342-360, 1937.

Cardellini, S.: The Early Warning System of Ancona for Managing and Reducing Landslide Risks, Climate change adaptation and disaster risk reduction, making cities resilient conference, Stockholm, Sweden, 17 May 2011, available at: http://www.unisdr.org/ we/inform/events/19823 (last access: 15 October 2013), 2011.

Casagli, N., Catani, F., Del Ventisette, C., and Luzi, G.: Monitoring, prediction, and early warning using ground-based radar interferometry, Landslides, 7, 291-301, 2010.

Chantry, R., Pedrazzini, A., Jaboyedoff, M. and Stampfli, E.: Caractérisation, suivi et assainissement des instabilities rocheuses à la carrier d'Arvel, in: Les dangers naturels en Suisse: pratiques et développement, Comptes rendus de la deuxième Journée de Rencontre sur les Dangers Naturels, Lausanne, Switzerland, 18 February 2011, 243-261, 2013 (in French).

Cornforth, D. H.: Landslides in Practice: Investigation, Analysis and Remedial/Preventive Options in Soils, John Wiley \& Sons, Hoboken, New Jersey, 624 pp., 2005.

Corominas, J. and Santacana, N.: Stability analysis of the Vallcebre translational slide, Eastern Pyrenees (Spain) by means of a GIS, Nat. Hazards, 30, 473-485, 2003.

Corominas, J., Moya, J., Ledesma, A., Lloret, A., and Gili, J.: Prediction of ground displacements and velocities from groundwater level changes at the Vallcebre landslide (Eastern Pyrenees, Spain), Landslides, 2, 83-96, 2005.

Costa, J. E. and Schuster, R. L.: The formation and failure of natural dams, Geol. Soc. Am. Bull., 100, 1054-1068, 1988. 
Cotecchia, V.: The Second Hans Cloos Lecture: Experience drawn from the great Ancona landslide of 1982, Bull. Eng. Geol. Env., $65,1-41,2006$.

Couture, R., Bobrowsky, P. T., Blais-Stevens, A., Wang, B., and VanDine, D. F.: An introduction to the Canadian technical guidelines and best practices related to landslides, in: Landslides and Engineering Slopes: Protecting Society through Improved Understanding, Proceedings of the 11th International and 2nd North American Symposium on Landslides and Engineered Slopes, Banff, Canada, 3-8 June 2012, 217-222, 2012.

Crosta, G. B. and Agliardi, F.: Failure forecast for large rock slides by surface displacement measurements, Can. Geotech. J., 40, 176-191, 2003.

Cruden, D. and Krahn, J.: A re-examination of the geology of Frank Slide, Can. Geotech. J., 10, 581-591, 1973.

Cruden, D. and Varnes, D.: Landslides Types and Processes, in: Landslides, Investigations and Mitigations, Transportation Research Board, Special Report 247, edited by: Turner, A. and Schuster, R., Washington, DC, 36-75, 1996.

Dash, N. and Gladwin, H.: Evacuation Decision Making and Behavioral Responses: Individual and Household, Nat. Hazards Rev., 8, 69-77, 2007.

Federico, A., Popescu, M., Elia, G., Fidelibus, C., Internò, G., and Murianni, A.: Prediction of time to slope failure: a general framework, Environ. Earth Sci., 66, 245-256, 2012.

Fell, R., Ho, K. K. S., Lacasse, S., and Leroi, E.: A framework for landslide risk assessment and management, in: Landslide Risk Management, edited by: Hungr, O., Fell, R., Couture, R., and Eberhardt, E., Proceedings of the International Conference on Landslide Risk Management in Vancouver, Canada, 31 May-3 June 2005, 3-25, 2005.

Froese, C.: Lessons Learned from 10 Years of Early Warning at Turtle Mountain, Alberta, Canada, in: Proceedings of the 1st International Workshop on Warning Criteria for Active Slides, Courmayeur, Italy, 10-12 June 2013, 48-49, available at: http: //www2.ggl.ulaval.ca/iwwcas/, 2013.

Froese, C. and Moreno, F.: Structure and components for the emergency response and warning system on Turtle Mountain, Alberta, Canada, Nat. Hazards, 24 pp., doi:10.1007/s11069-011-9714-y, 2011.

Fukuzono, T.: Recent Studies on Time Prediction of Slope Failure, Landslide News, 4, 9-12, 1990.

Gili, J., Corominas, J., and Riuz, J.: Using Global Positioning System techniques in landslide monitoring, Eng. Geol., 55, 167-192, 2000.

Holtz, R. D. and Schuster, R. L.: Stabilization of soil slopes, in: Landslides, Investigations and Mitigations, Transportation Research Board, Special Report 247, edited by: Turner, A. and Schuster, R., Washington, DC, 439-473, 1996.

Hong Kong Slope Safety: available at: http://hkss.cedd.gov.hk/hkss/ eng/index.aspx, last access: 19 November 2012.

Intrieri, E., Gigli, G., Casagli, N., and Nadim, F.: Brief communication "Landslide Early Warning System: toolbox and general concepts", Nat. Hazards Earth Syst. Sci., 13, 85-90, doi:10.5194/nhess-13-85-2013, 2013

Jaboyedoff, M., Oppikofer, T., Derron, M.-H., Blikra, L. H., Böhme, M. and Saintot, A.: Complex landslide behaviour and structural control: a three-dimensional conceptual model of Åknes rockslide, Norway, in: Slope Tectonics, Special Publication 351, edited by: Jaboyedoff, M., Geological Society of London, 147161, 2011.

Jaboyedoff, M., Derron, M.-H., Pedrazzini, A., Blikra, L., Froese, C., Hermanns, R. H., Oppikofer, T., Böhme, M., and Stead, D.: Fast assessment of susceptibility of massive rock instabilities, in: Landslides and Engineering Slopes: Protecting Society through Improved Understanding, Proceedings of the 11th International and 2nd North American Symposium on Landslides and Engineered Slopes, Banff, Canada, 3-8 June 2012, 459-465, 2012.

Jakob, M., Owen, T., and Simpson, T.: A regional real-time debris-flow warning system for the District of North Vancouver, Canada, Landslides, 9, 165-178, 2012.

Jongmans, D. and Garambois, S.: Geophysical investigations of landslides. A review, Bulletin de la Société Géologique de France, 178, 101-112, 2007.

Kaldhol, H. and Kolderup, N.-H.: Skredet i Tafjord 7. April 1934, Bergens Museums Årbok 1936 Naturvitenskapelig Rekke, 11, 115, 1936.

Keefer, D. K., Wilson, R. C., Mark, R. K., Brabb, E. E., Brown, W. M., Ellen, S. D., Harp, E. L., Wieczorek, G. F., Alger, C. S., and Zatkin, R. S.: Real time landslide warning system during heavy rainfall, Science, 238, 921-925, 1987.

Korup, O.: Recent research on landslide dams - a literature review with special attention to New Zealand, Progr. Phys. Geogr., 26, 206-235, 2002.

Lacasse, S. and Nadim, F.: Landslide Risk Assessment and Mitigation Strategy, in: Landslides - Disaster Risk Reduction, edited by: Sassa, K. and Canuti, P., Springer-Verlag Berlin Heidelberg, 31-61, 2009.

Lapointe, F., Baulne, J., Bélanger, L., Breton, A., Camirand, J., Chevalier, R., Cloutier, R., Godbout, M., Lepage, H., Thibault, M.-T., Vecerina, C., Bilodeau, D., des Groseilliers, L., and Haché, M.: Gestion de la qualité - Document de principes sur la qualité dans les enquêtes, Public report, Institut sur la statistique du Québec, Québec, Canada, 65 pp., 2010 (in French).

L'Heureux, J.-S., Glimsdal, S., Longva, O., Hansen L., and Harbitz, C. B.: The 1888 shoreline landslide and tsunami in Trondheimsfjorden, central Norway, Mar. Geophys. Res., 32, 313-329, 2011.

Lovisolo, M., Ghirotto, S., Scardia, G., and Battaglio, M.: The use of Differential Monitoring Stability (D.M.S.) for remote monitoring of excavation and landslide movements, in: Proceedings of the Sixth International Symposium on Field Measurements in Geomechanics, edited by: Myrvol, A., Oslo, Balkema, 519-524, 2003.

Mainsant, G., Larose, E., Brönnimann, C., Jongmans, D., Michoud, C., and Jaboyedoff, M.: Ambient seismic noise monitoring of a clay landslide: Toward failure prediction, J. Geophys. Res., 117, F01030, doi:10.1029/2011JF002159, 2012.

Mainsant, G., Jongmans, D., Chambon, G., Larose, E., and Baillet, L.: Shear-wave velocity as an indicator for rheological changes in clay materials: Lessons from laboratory experiments, Geophys. Res. Lett., doi:10.1029/2012GL053159, in press, 2013.

McConnell, R. G. and Brock, R. W.: Report on the Great Landslide at Frank, Alberta, in: Annual Report for 1903, Canada Department of the Interior, 1904.

Mercogliano, P., Segoni, S., Rossi, G., Sikorsky, B., Tofani, V., Schiano, P., Catani, F., and Casagli, N.: Brief communication "A prototype forecasting chain for rainfall induced shal- 
low landslides", Nat. Hazards Earth Syst. Sci., 13, 771-777, doi:10.5194/nhess-13-771-2013, 2013.

Meyer, N. K., Dyrrdal, A. V., Frauenfelder, R., Etzelmüller, B., and Nadim, F.: Hydrometeorological threshold conditions for debris flow initiation in Norway, Nat. Hazards Earth Syst. Sci., 12, 3059-3073, doi:10.5194/nhess-12-3059-2012, 2012.

Michoud, C., Abellán, A., Derron, M.-H., and Jaboyedoff, M. (Eds.): SafeLand deliverable 4.1.: Review of Techniques for Landslide Detection, Fast Characterization, Rapid Mapping and Long-Term Monitoring, 2nd Edition, European Project SafeLand, Grant Agreement No. 226479, 401 pp., available at: http: //www.safeland-fp7.eu, 2012.

Michoud, C., Derron, M.-H., Jaboyedoff, M., Abellán, A., Bazin, S., and Blikra, L.: On the importance of landslide conceptual models by integrating and coupling different souces of data to set pertinent thresholds and proper EWS, in: Proceedings of the 1st International Workshop on Warning Criteria for Active Slides, Courmayeur, Italy, 10-12 June 2013, 19-20, available at: http://www2.ggl.ulaval.ca/iwwcas/, 2013.

Mileti, D. and Sorensen, J.: Communication of emergency public warnings - A social science perspective and state-of-the-art assessment, Oak Ridge National Laboratory, Tennessee, USA, 166 pp., 1990.

Monserrat, O., Moya, J., Luzi, G., Crosetto, M., Gili, J. A., and Corominas, J.: Non interferometric GBSAR measurement - Application to the Vallcebre Landslide (Eastern Pyrenees, Spain), Nat. Hazards Earth Syst. Sci., submitted, 2013.

Moreno, F. and Froese, C.: ERCB/AGS Roles and Responsibilities Manual for the Turtle Mountain Monitoring Project, Alberta, ERCB/AGS, Open File Report 2009-06, 35 pp., available at: http://www.ags.gov.ab.ca/geohazards/turtle_mountain/, 2009.

Navratil, O., Liébault, F., Bellot, H., Travaglini, E., Theule, J., Chambon, G., and Laigle, D.: High-frequency monitoring of debris-flow propagation along the Réal Torrent, Southern French Prealps, Geomorphology, 201, 157-171, 2013.

Oppikofer, T., Jaboyedoff, M., Blikra, L., Derron, M.-H., and Metzger, R.: Characterization and monitoring of the Åknes rockslide using terrestrial laser scanning, Nat. Hazards Earth Syst. Sci., 9, 1003-1019, doi:10.5194/nhess-9-1003-2009, 2009.

Ostrom, E.: A Behavioral Approach to the Rational Choice Theory of Collective Action: Presidential Address, American Political Science Association, 1997, The American Political Science Review, 92, 1-22, 1998.

Piteau, D. R. and Peckover, F. L.: Engineering of Rock Slope, in: Landslides, Analysis and Control, Transportation Research Board, Special Report 176, edited by: Schuster, R. L. and Krizek, R. J., Washington, DC, 192-228, 1978.

Riegl: available at: http://www.riegl.com/media-events/newsletter/ 0512-rimonitor-and-rimining/, last access: 11 July 2013.

Roth, M.: Microseismic monitoring at the unstable rock slope at Åknes, Norway, in: SafeLand deliverable 4.1.: Review of Techniques for Landslide Detection, Fast Characterization, Rapid Mapping and Long-Term Monitoring, 2nd Edn., edited by: Michoud, C., Abellán, A., Derron, M.-H., and Jaboyedoff, M., European Project SafeLand, Grant Agreement No. 226479, 313-317, available at: http://www.safeland-fp7.eu, 2012.
Saito, M.: Forecasting time of slope failure by tertiary creep. In: Proceedings of the 7th International Conference on Soil Mechanics and Foundation Engineering, Mexico City, Mexico, 677-683, 1969.

Spillman, T., Maurer, H., Green, G. A., Heincke, B., Willenberg, H., and Husen, S.: Microseismic investigation of an unstable mountain slope in the Swiss Alps, J. Geophys. Res., 112, B07301, doi:10.1029/2006JB004723, 2007.

Stumpf, A., Kerle, N., and Malet, J.-P. (Eds.): SafeLand deliverable 4.4.: Guidelines for the selection of appropriate remote sensing technologies for monitoring different types of landslides, European Project SafeLand, Grant Agreement No. 226479, 91 pp., available at: http://www.safeland-fp7.eu, 2011.

Tarchi, D., Casagli, N., Moretti, S., Leva, D., and Sieber, A. J.: Monitoring landslide displacements by using ground-based synthetic aperture radar interferometry: Application to the Ruinon landslide in the Italian Alps, J. Geophys. Res.-Solid Earth, 108, 2387, doi:10.1029/2002JB002204, 2003.

Terzaghi, K.: Mechanism of Landslides, The Geological Society of America, Engineering Geology (Berkley) Volume, 83-123, 1950.

Tofani, V., Segoni, S., Catani, F., and Casagli, N. (Eds.): SafeLand deliverable 4.5.: Evaluation report on innovative monitoring and remote sensing methods and future technology, European Project SafeLand, Grant Agreement No. 226479, 280 pp., available at: http://www.safeland-fp7.eu, 2012.

Tofani, V., Segoni, S., Agostini, A., Catani, F., and Casagli, N.: Technical Note: Use of remote sensing for landslide studies in Europe, Nat. Hazards Earth Syst. Sci., 13, 299-309, doi:10.5194/nhess-13-299-2013, 2013.

Travelletti, J. and Malet, J.-P.: Characterization of the 3D geometry of flow-like landslides: A methodology based on the integration of heterogeneous multi-source data, Eng. Geol., 128, 30-48, 2012.

Troisi, C. and Negro, N.: Managing of EW systems by public agencies: related problems, in: Proceedings of the 1st International Workshop on Warning Criteria for Active Slides, Courmayeur, Italy, 10-12 June 2013, 43-45, available at: http://www2.ggl. ulaval.ca/iwwcas/, 2013.

Turner, A. and Schuster, R. (Eds.): Landslides, Investigations and Mitigations, Transportation Research Board, Special Report 247, Washington, DC, 685 pp., 1996.

UN-ISDR: Terminology on Disaster Risk Reduction, United Nation International Strategy for Disaster Reduction, Geneva, Switzerland, 35 pp., 2009.

Vaciago, G., Rocchi, G., Riba, I., Davì, M., Bianchini, A., Callerio, A., and Costi, M. (Eds.): SafeLand deliverable 5.1.: Compendium of tested and innovative structural, non-structural and risk-transfer mitigation measures for different landslide types, European Project SafeLand, Grant Agreement No. 226479, 340 pp., available at: http://www.safeland-fp7.eu, 2011.

Wyllie, D. C. and Mah, C. W.: Rock Slope Engineering, Civil and Mining, 4th Edn., Taylor \& Francis, London and New-York, 2004. 